\title{
Extrahepatic Bile Duct Squamous Cell Carcinoma
}

National Cancer Institute

\section{Source}

National Cancer Institute. Extrahepatic Bile Duct Squamous Cell Carcinoma. NCI

Thesaurus. Code C5777.

A carcinoma that arises from the extrahepatic bile ducts. It is composed entirely by malignant squamous epithelial cells. 